\title{
CLIMATE CHALLENGES AND SOLUTIONS IN SOIL TILLAGE
}

\author{
BOTTLIK, L. -CSORBA, SZ. - GYURICZA, CS. - KENDE, Z. - BIRKÁS, M.* \\ Crop Production Institute, Faculty of Agricultural and \\ Environmental Sciences, Szent István University, \\ 2100 Gödöllö, Páter K. u. 1., Hungary \\ (phone: +36-28-522-000; fax: +36-28-410-804) \\ *Corresponding author \\ e-mail:birkas.marta@mkk.szie.hu \\ (Received $15^{\text {th }}$ September 2013; accepted $17^{\text {th }}$ December 2013)
}

\begin{abstract}
The aim of this paper was to study the effects of climate induced phenomena occurred in arable soils in the first half of year, 2013. The problem was investigated in a long-term trial on a preserved Chernozem soil and further assessments were performed on Luvisols and a Gleysol which have seriously suffered from climate extremes. Eight types of the soil deterioration were studied from the formation to the state that has changed for the worse. These phenomena were as follows (1) dust formation in the soil surface as the effect of the periodic frost, (2) silting of the dust, due to the periodic and heavy rains, (3) dust leaching into the soil and extending the former compacted layer, (4) soil settling due to the repeated rainfall, (5) strong crust formation in the silted surface both in soils to be unsown and in the rows of the crops. (6) remaining the crusty structure in long-term, (7) over compacting of the seedbed-base, (8) limited crop rooting in the over settled soils. Soil condition improvement may be expected to take place after the passage of 2-3 years, in the wake of soil conservation tillage practices.
\end{abstract}

Keywords: Dust formation, surface silting, crusting, dust leaching, soil settling

\begin{abstract}
Absztrakt. Klímakihívások és talajművelési megoldások. A tanulmány a 2013. év első félévében csernozjom, erdő és glejes talajokon bekövetkezett klímakárok értékelésére vállalkozik. Nyolc káros klíma jelenség kerül bemutatásra a kialakulástól a súlyosbodásig, amelyek (1) felszínporosodás a fagyok hatására, (2) felszín eliszapolódás az ismétlődő esők nyomán, (3) por lemosódás a legközelebbi tömör rétegig, (4) erős ülepedés, (5) káros felszín kérgesedés, (6) a kérgesedés tartós fennmaradása, (7) a magágy-alap túltömörödése, (8) gyökér deformálódás. A cikk a kár megelőzés és gyógyítás módszereit is bemutatja.
\end{abstract}

\section{Introduction}

Extreme climate phenomena, for instance drought stress, water deficit or waterlogging, hail storms etc. have been afflicted the soils of the Carpathian basin in the last decade. The fundamental appearance of the climate damage is extreme shortage or abundance of precipitation, causing over drying and/or over wetting of the soils even within a single growing season (Garamvölgyi and Hufnágel, 2013; Ladányi et al., 2003). As Szalai and Lakatos (2013) noted, the tendencies in the precipitation sums, the number of precipitation events with threshold values, especially the more intense rain events shows tendencies having serious effects on the available water amount and the surface water balance. Classic authors have long been preoccupied with climate extremes having adverse impacts on agricultural production (e.g. Milhoffer, 1897). From the aspect of cropping the damage caused by the underlying factor is also affected by the site parameters, the actual soil fertility, nutrient supply and water regime (Várallyay, 2013). Research findings show that agricultural activities have contributed to climate change and that at the same time agriculture is one of the sectors adversely 
affected by climate damage (Jolánkai et al., 2013). Soil is an environmental element labelled by a variable state and quality, renewed or degraded (Várallyay, 2011). This renewal capability of the soil can be maintained by continuous treatment carefully aligned to the prevailing circumstances. Therefore the primary task of tillage is to maintain favourable soil quality and fertility and to prevent climate sensitiveness.

Birkás (2011) found, that the state of soils is another modifying factor in the degree of the climate stress. Some of the soil condition defects are visible to the naked eye, e.g. the dust formation, surface silting, surface crusting, clod and dust formation, however it does not help prevention since consequences are not being considered to be as serious as they actually are (Kalmár et al., 2013). Defects occurred in the soil, e.g. dust being leached to the compacted layer close to the surface, growing thickness of the compacted layer, extending of the crust on the top of the soil, increased settling of the loosened soil, are assumed to have been caused by lack of knowledge of their existence or their consequences (Kalmár et al., 2011; Birkás et al., 2012).

As authors (Baumhardt et al., 2004; Birkás, 2012; Kalmár et al., 2013; Várallyay, 2013) have already stressed, maintaining good soil quality and soil condition may reduce the effects of climatic extremes and degree of the damage.

\section{Materials and methods}

The problem referred to in this paper was studied in a long-term trial that has been underway since 2002 in a field of the Experimental and Training Farm of the Szent István University, located in Heves county, near to the town Hatvan $\left(47^{\circ} 41^{\prime} \mathrm{N}, 19^{\circ} 36^{\prime} \mathrm{E}\right.$, $136 \mathrm{~m}$ a.s.1.). The research site is flat and the soil - Chernic Chernozem soil by WRB (2006) with a clay loam texture - is moderately sensitive to compaction (Csorba et al., 2011, 2012). Soil assessment was extended to the surrounding area of an approx. $10 \mathrm{~km}$ radius with similar type of soil. In this site the long-term annual precipitation is 580 $\mathrm{mm}$. The last five years' precipitation figures are as follows: dry (2011: $-283 \mathrm{~mm}, 2012$ : $-286 \mathrm{~mm})$ and rainy $(2010+371 \mathrm{~mm}, 2013$ in the first half of year $+100 \mathrm{~mm})$. Year 2009 was dry in the growing season. The experiment was of the single-factor type, in random stripe arrangement in four replications (Sváb, 1981), in which the following six treatments were applied: direct drilling (DD), disking $(15 \mathrm{~cm}, \mathrm{D})$, shallow and medium deep cultivator $(15 \mathrm{~cm} \mathrm{SC}, 22 \mathrm{~cm} \mathrm{C})$ ploughing $(32-33 \mathrm{~cm}, \mathrm{P})$ followed by surface consolidation and loosening $(40 \mathrm{~cm}, \mathrm{~L})$. Table 1 presents types of the soil phenomenon and the time of the measurements.

Table 1. Assessed soil state phenomena and place and time of measurements

\begin{tabular}{|c|c|c|c|}
\hline Phenomenon & Soil & County & Time \\
\hline Dust formation by frost & Chernozem & Heves & March 2010, 2013 \\
\hline Surface silting & Chernozem & Heves & April 2013 \\
\hline $\begin{array}{l}\text { Dust leaching and extending } \\
\text { former compacted layer }\end{array}$ & Chernozem & Heves & $\begin{array}{l}\text { Growing season } \\
2010,2013\end{array}$ \\
\hline Soil settling & \multirow{2}{*}{$\begin{array}{l}\text { Chernozem, } \\
\text { forest, gley }\end{array}$} & \multirow{2}{*}{$\begin{array}{l}\text { Borsod-Abaúj- } \\
\text { Zemplén; Baranya, } \\
\text { Virovitica-Podravina }\end{array}$} & \multirow{2}{*}{$\begin{array}{l}\text { November 2012- } \\
\text { May } 2013\end{array}$} \\
\hline $\begin{array}{l}\text { Water-logging } \\
\text { Extending of seedbed base }\end{array}$ & & & \\
\hline $\begin{array}{l}\text { Crust formation, } \\
\text { Crust thickness }\end{array}$ & Chernozem & Heves & $\begin{array}{l}\text { September 2012- } \\
\text { July } 2013\end{array}$ \\
\hline
\end{tabular}


The measurements were completed and evaluated in accordance with the applicable standards (Csorba et al., 2011); Soil Sampling Protocol, JRC, 2010). Classic soil state measurement methods (Dvoracsek et al., 1957) were also taken into account. Soil surface silting and crusting occurred by rains and drying was recorded by visual assessment on a notation grid. The areas observed were $50 \mathrm{~cm} \times 50 \mathrm{~cm}$ per variants and by using a quadrate device in six replications per plot. The thickness of the crusts and extension of seedbed base were measured on a soil cube (edge of $30 \mathrm{~cm}$ ) extracted from the concerned areas. Dust leaching and soil settling were also measured on soil cubes and by using a handheld Szarvas-type penetrometer having a $1.0 \mathrm{~cm}^{2}$ cone and a $60^{\circ}$ apex, at soil depths of $55 \mathrm{~cm}$ at each $5 \mathrm{~cm}$ increment, in at least six repetitions.

Further assessments were performed in other counties on forests (Luvisols) and gley (Gleysol) soils which have seriously suffered from extreme climate in the first half of year 2013 (Table 1).

The data were evaluated with the method of variance analysis, by Sváb (1981) and by using the Microsoft Excel 2010 program.

\section{Results and discussion}

\section{Climate induced phenomena occurred in arable soils in the first half of year, 2013}

Soil deterioration has strongly been occurred mainly in three periods, that is at the end of the winter, in the beginning of the spring (thereafter rainy period) and in the beginning of the summer (following May rains).

\section{Dust formation in the soil surface as the effect of the periodic frost}

The strong dust formation by the frost effect in the cold period is considered to the climate induced damage. The frost effect is regrettably misunderstood in the practice, because the "frost-crumbs" seemed to crumbs, however catching some frost-crumbs they turn to dusts. The dusting effect of the frost depends on the length of the cold period, the repeat of the frost, and largeness of the soil surface exposed to the frost. A large, cloddy soil surface is highly suffered from the frost effect than a smaller, levelled soil surface. For this reason, the ratio of the dust that can be found in the surface layer at the very beginning of the spring is also referred to the autumnal soil tillage quality.

The ratio of the dust formation can be ranked by the degree of the damage, that is:

$$
\begin{aligned}
& <10 \% \text { : slight (negligible) } \\
& 11-30 \% \text { : conspicuous } \\
& 31-50 \% \text { : risky } \\
& 51-70 \% \text { : serious } \\
& 71-100 \% \text { : very serious }
\end{aligned}
$$

Fig. 1 presents data of the dust ratio measured in soil surface in case of different tillage methods and after a cold and a mild winter.

There were significant differences between two types of winter' effect and between tillage variants. The dust formation was found higher after a cold winter included frost phenomenon in number and mainly in ploughed soil left it in cloddy state in autumn. Moreover, the degraded soil (Pdegr) seems in danger to a high degree than soil that has been preserved in long term. In the trial the P variant is also ploughing, but the surface is usually decreased by packer just when ploughed, and for this reason the frost effect 
has been succeeded to a lesser extent. References were no found in concerning literature about pulverisation effect of the frost. However, Dagesse (2013) proved a lower aggregate stability when freeze and thaw changed in cycles. Others, e.g. Sinha and Cherkauer (2010) threw on further threat, that is increasing the frequency of freeze-thaw cycles may increase the risk of soil erosion in the arable sites.

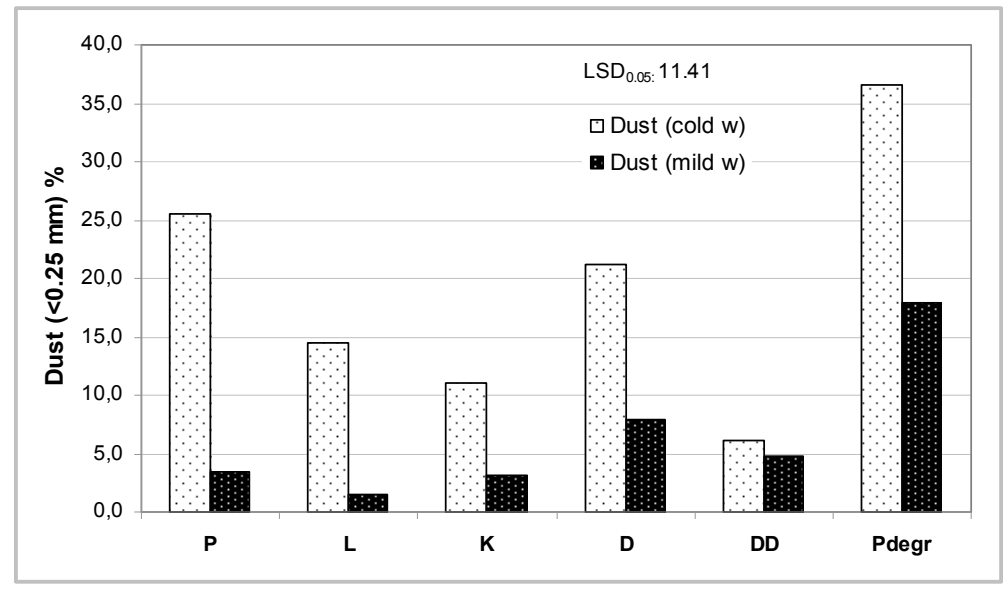

Figure 1. Dust ratio in soils following a cold (2013) and a mild (2010) winter (Hatvan) Legend: P: ploughing and levelling, L: loosening. $K$ : cultivator use, D: disking, $D D$ : direct drilling, Pdegr: ploughing, no levelling, in degraded soil

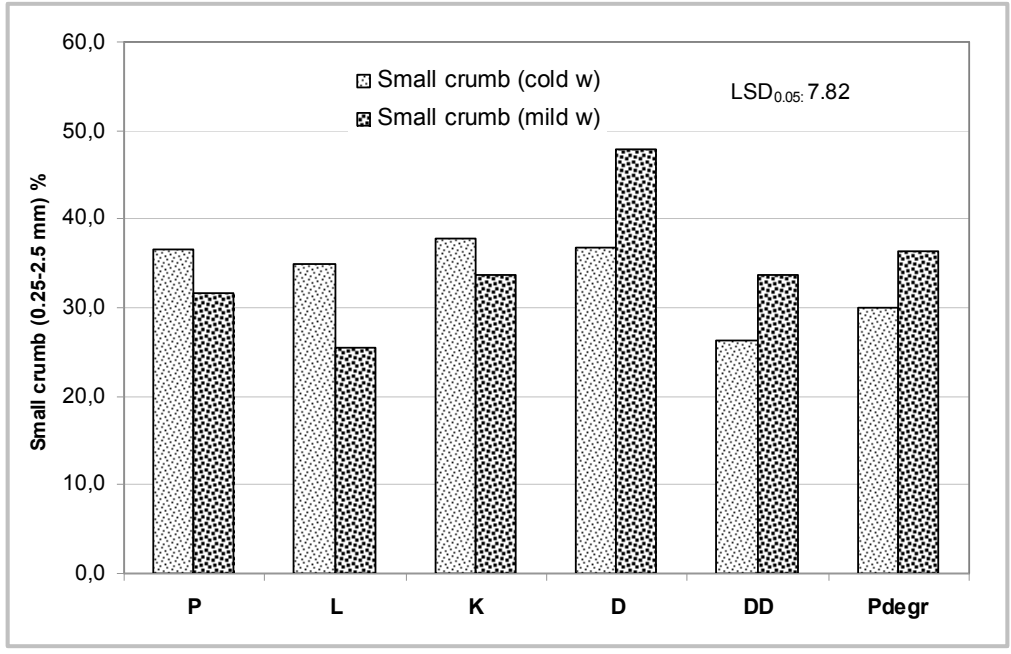

Figure 2. Small crumb ratio in soils following a cold (2013) and a mild (2010) winter (Hatvan) Legend: see Figure 1.

Fig. 2 shows ratio of the small crumbs assessed in soil surface at different tillage methods and after two types of winter. The small crumb formation, on account of pulverisation requires higher attention following critical periods (e.g. winter, rainy spring or summer). According to the climate and farming circumstances the small crumbs may transform to crumb or, in case of the unfavourable influences they pulverise by progressive stages. The frost effect was higher at the D variant that is in disked soil, and after a mild winter, and lowest in the loosened (L) soil following a cold 
winter. The small crumb ratio was showed a normal level (while greater part of the fractions transformed to dust) in the degraded soil (Pdegr) in both period.

\section{Silting of the dusty soil}

The silting is the outcome of the dust formation in recurrent rainy periods and aftereffect of this phenomenon is the crusting in warm and dry days. The degree of the silting, out of the precipitation depends on the soil quality (that is degraded or preserved), and on the covering state of the surface. As Morris et al. (2010) outlined that soil surface exposed to rainfall often leads to the breakdown of aggregates. This process leads to the displacement of small soil particles forming a more continuous structure (mud film) that creates a surface seal and later on a surface crust.

The ratio of the surface silting can be ranked by the degree of the damage, similarly to the dust formation (e.g. $<10 \%$ is slight, and $31-50 \%$ is risky, and $51-70 \%$ is serious etc.). Fig. 3 represents data measured in silted soil surface in the end of the rainy periods. On the basis of the ranking the degree of the damage at the variant bare surface and degraded soil is considered to be serious, at the variant of bare surface and preserved soil and the covered and degraded soil to be risky, however, at the covered surface and the preserved soil is seemed negligible. Surface silting was significantly decreased by the surface cover and in the same way a significantly lower ratio of silting occurred in the preserved soil $(P>0.01)$.

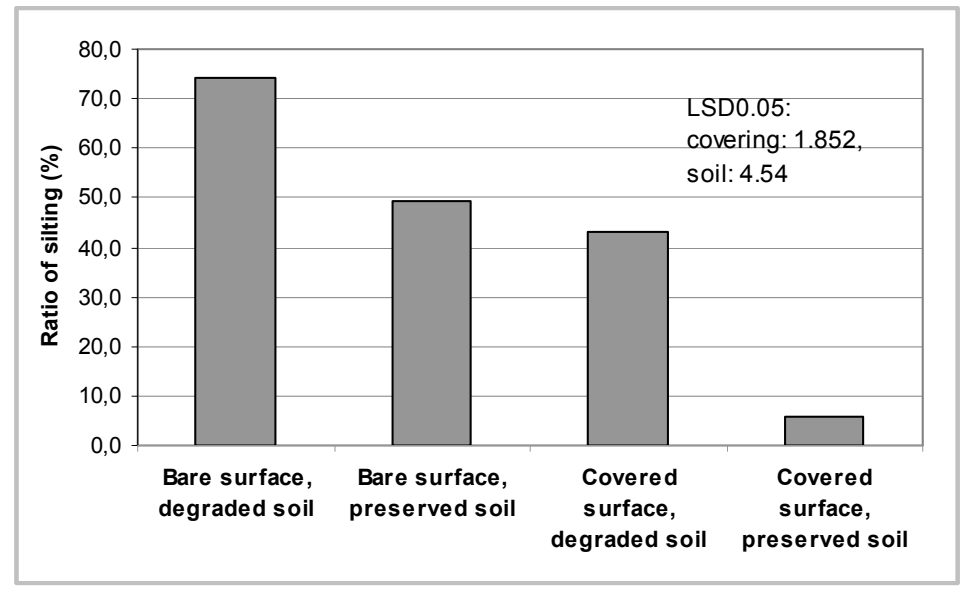

Figure 3. Impacts of surface cover and soil quality on soil surface silting in a rainy period (Hatvan, April, 2013)

\section{Dust leaching}

Dust formation in the soil surface has become a noteworthy phenomenon considering the combined effect of the multi-traffic tillage and the extreme climate. The dust in soil surface is usually labile matter that may remove by wind or rainwater (Baumhardt et al., 2007). Some parts of the dust remain in the surface as a silt film and other parts leach into the soil and agglomerate to the nearest compact layer and increase thickness of this layer (Fig. 4). 
The leached dust mixed with soil mineral particles constitutes a most firm condition (Dexter, 1988; Kalmár et al., 2011). This phenomenon explains the formation of large clods at any loosening tillage and higher resistance of soil. Close coherence was found between dust ratio of the surface soil layer and the extension of the soil compaction (Fig.4). After all the increase of the dust ratio in the surface layer and increase of the leached ratio that aggravate the thickness of the former compacted layer. Birkás (2012) and Gao et al. (2012) proved that compacted layer is considered to be serious when that increases soil penetration resistance and causes water stagnation above the consoled layer and it extends of 20-25 mm. It was found that soil cover is assumed to have played an important role in retaining the moisture moving up from the deeper layers of soil without any compact layers that would have impeded water transport - towards the surface.

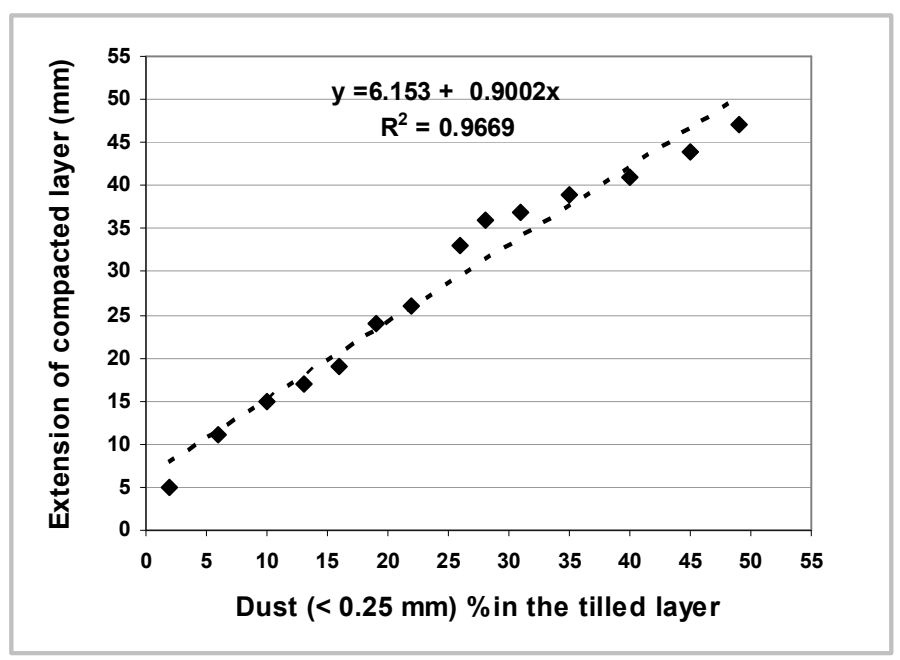

Figure 4. Relations between surface dust ratio and the extension of the compacted layer

\section{Soil settling}

Soil settling has become a typical phenomenon in the regional soils in the first half of year, 2013 but it strongly depended on the soil quality. A quite intensive settling effect was found on degraded soils and on soils having low organic matter content (Table 2). According to Lamandé and Schjønning (2011) the transmission of stresses in the soil profile is leading to either persistent deformation or elastic deformation.

Table 2. Degree of the soil settling (mm) in different sites (November, 2012 - April, 2013)

\begin{tabular}{c|c|c|c|c|c|c|c}
\hline \multicolumn{2}{c|}{$\begin{array}{c}\text { Chernozem soil } \\
\text { (Hatvan) }\end{array}$} & \multicolumn{2}{c|}{$\begin{array}{c}\text { Forest soil } \\
\text { (Northern Hungary) }\end{array}$} & \multicolumn{2}{c|}{$\begin{array}{c}\text { Forest soil } \\
\text { (South-Hungary) }\end{array}$} & \multicolumn{2}{c}{$\begin{array}{c}\text { Gley } \\
\text { (Slavonia) }\end{array}$} \\
\hline Prevented & Degraded & Prevented & Degraded & Prevented & Degraded & Prevented & Degraded \\
\hline 11 & 37 & 19 & 43 & 21 & 50 & 19 & 36 \\
\hline
\end{tabular}

The extension of the soil settling, as compared to the soil state at sowing or after surface levelling, can be ranked by the degree of the damage, that is: 
$<15 \mathrm{~mm}$ : slight (normal)

16-25 mm: conspicuous

26-45 mm: risky

46-75 mm: serious

75-100 mm: very serious

On the basis of the ranking the degree of the settling was slight $(11 \mathrm{~mm})$ in the prevented soil (in field trial), and showed a remarkable stage $(19-21 \mathrm{~mm}$ ) in other prevented soils. However the degree of the settling was found to be risky and serious at the degraded soil variants.

\section{Over-consolidation of the seedbed-base}

In April, 2013 the seedbed preparation was completed in soils that were dry and crusty in the surface and wet below 5-6 cm and for this reason seedbed-base turned to over-compacted. The natural drying of the soils was lasted considering the hard and thick crust in the surface and by this means seedbed preparation tools have inevitably kneaded and thickened the seedbed base. Similar findings were cited by Fang et al. (2007), Guo and Wang (2013), and by Mueller et al. (2013).

Table 3. Depth of crops rooting at different soil condition (July, 2013)

\begin{tabular}{|l|l|l|c|c|c|c|}
\hline \multirow{2}{*}{ Crop } & & \multicolumn{5}{|c|}{ Extension of seed-bad base (cm) } \\
\cline { 2 - 7 } & Roots & $\leq 5.0$ & $5.1-10.0$ & $10.1-15.0$ & $15.1-20.0$ & $\geq 25$ (extreme) \\
\hline \multirow{3}{*}{ Mailseed rape } & main & 48.2 & 45.2 & 41.1 & 32.8 & 26.7 \\
\cline { 2 - 7 } & lateral & 25.8 & 22.0 & 20.1 & 16.3 & 12.8 \\
& main & 32.1 & 29.4 & 27.4 & 25.1 & 24.5 \\
\cline { 2 - 7 } & lateral & 22.7 & 20.3 & 17.3 & 15.5 & 12.2 \\
\hline \multirow{2}{*}{ Sunflower } & main & 40.6 & 38.6 & 36.3 & 32.8 & 30.5 \\
\cline { 2 - 7 } & lateral & 24.1 & 22.5 & 20.5 & 18.1 & 15.2 \\
\hline
\end{tabular}

Due to the rainy period after crops sprouting, the main roots have penetrated the compacted layer (Table 3). However the lateral roots has grown horizontally (mostly above the seedbed base). This phenomenon is free from risk in a normal season when precipitation soaks the soil every 7-10 days. This is highly risky in a long-term dry period while main root is capable only to water intake from the deeper soil layers. For this reason, crops are more sensitive to the drought than in case of the normal rooting state.

\section{Crust formation}

Crust formation in the silted surface considering the frequency pays more attention because no similar serious damages occurred in the last decades. In spring 2013 crusts have been formed both in soils to be unsown and in the row spacing of the winter and spring crops. Crust development follows several stages under the effects of cumulated rainfall and this phenomenon has followed with appropriate attention in the international research (e.g. Fang et al., 2007; Gallardo-Carrera et al., 2007; Mueller et al., 2013). 
The degree of the crusting can be ranked by the ratio of the damaged surface in a unit area, that is:

$$
\begin{aligned}
& <10 \% \text { : slight (negligible) } \\
& 11-30 \% \text { : conspicuous } \\
& 31-50 \% \text { : risky } \\
& 51-70 \% \text { : serious } \\
& 71-100 \% \text { : very serious }
\end{aligned}
$$

Table 4 shows the changing of the crusted are in a long term preserved soil (in the experimental site) and in a soil to be in degraded state. The crust formation remained under risky degree over periods due to long-term soil conservation and carbon preserving tillage. However, a large crusted area was occurred at disking (D) variant after rainy period in the beginning of the growing season. This damage has gradually decreased parallel with the crop growth.

More serious crusting occurred at the Pdegr variant not only in stubble phase but during growing season as well. This finding may suppose that the cause of the crusting is the combined effect of the soil deterioration, and the soil silting in rainy periods (Birkás et al., 2012; Kalmár et al., 2013).

Table 4. Ratio of the crusted area at different soil tillage variants (Hatvan, Sept, 2012 July, 2013)

\begin{tabular}{l|c|c|c|c|c|c}
\hline Time & P & L & K & D & DD & Pdegr \\
\hline 24092012, covered stubble & 1 & 1 & 0.5 & 1 & 0 & $36.2^{* *}$ \\
\hline 22102012, after primary tillage & 0 & 0 & 0 & 0 & 0 & 0 \\
\hline 08032013, before sowing & 5.10 & 3.45 & 1.80 & 15.18 & 1.06 & 11.05 \\
\hline 08032013, after sowing & 0 & 0 & 0 & 0 & 0 & 0 \\
\hline $16042013^{*}$, after rainy period & 0.65 & 0.49 & 1.43 & 84.05 & 0.03 & 86.25 \\
\hline $\begin{array}{c}10052013, \text { sunny and windy } \\
\text { weather }\end{array}$ & 4.08 & 2.95 & 1.25 & 22.65 & 0.11 & 74.15 \\
\hline 13062013, dry weather & 3.72 & 2.57 & 1.65 & 11.32 & 1.17 & 72.35 \\
\hline 05072013 , dry and windy \\
$\begin{array}{c}\text { weather } \\
\text { weather }\end{array}$ & 3.13 & 2.38 & 1.20 & 9.85 & 0.88 & 65.05 \\
\hline 13072013 , very dry and windy & 10.52 & 7.10 & 3.13 & 13.41 & 2.29 & 50.75 \\
\hline
\end{tabular}

Legend: P: ploughing and levelling, L: loosening. K: cultivator use, $D$ : disking, $D D$ : direct drilling, Pdegr: ploughing, no levelling, in degraded soil,

*: between spring barley rows; **: bare surface

\section{Crust thickness}

Both ratio of the crusting and crust thickness is a suitable soil quality indicator and they may give information about progress of the degradation (Dvoracsek et al., 1957). The crust is typically appeared in acidic, alkaline, and clay soils, however it is endangered other soil types (chernozem, medium heavy forest, ameliorated meadow soils) if the degradation process has begun started (Gallardo-Carrera et al., 2007). Serious crust has occurred in soils desiccated rapidly in April 2013 after a long-term rainy period when soil silting was unavoidable.

The crust thickness can also be ranked by the extension of the crust, that is: 
$<5 \mathrm{~mm}$ : slight

6-15 mm: conspicuous

16-25 mm: risky

26-35 mm: serious

$>35 \mathrm{~mm}$ : very serious

Assessing the crust thickness at different soil quality and surface state (Fig. 5) a low degree of the damage can be stated at preserved soil variant (DD, K, L), mainly in stubble phase when surface was fully covered by stubble residues. The impact of disking (D) variant on crust formation shows the real risk of the applying disk tillage in long-term. Most serious crust formation was found at the Pdegr variant which calls attention again to the soil conservation requirements.

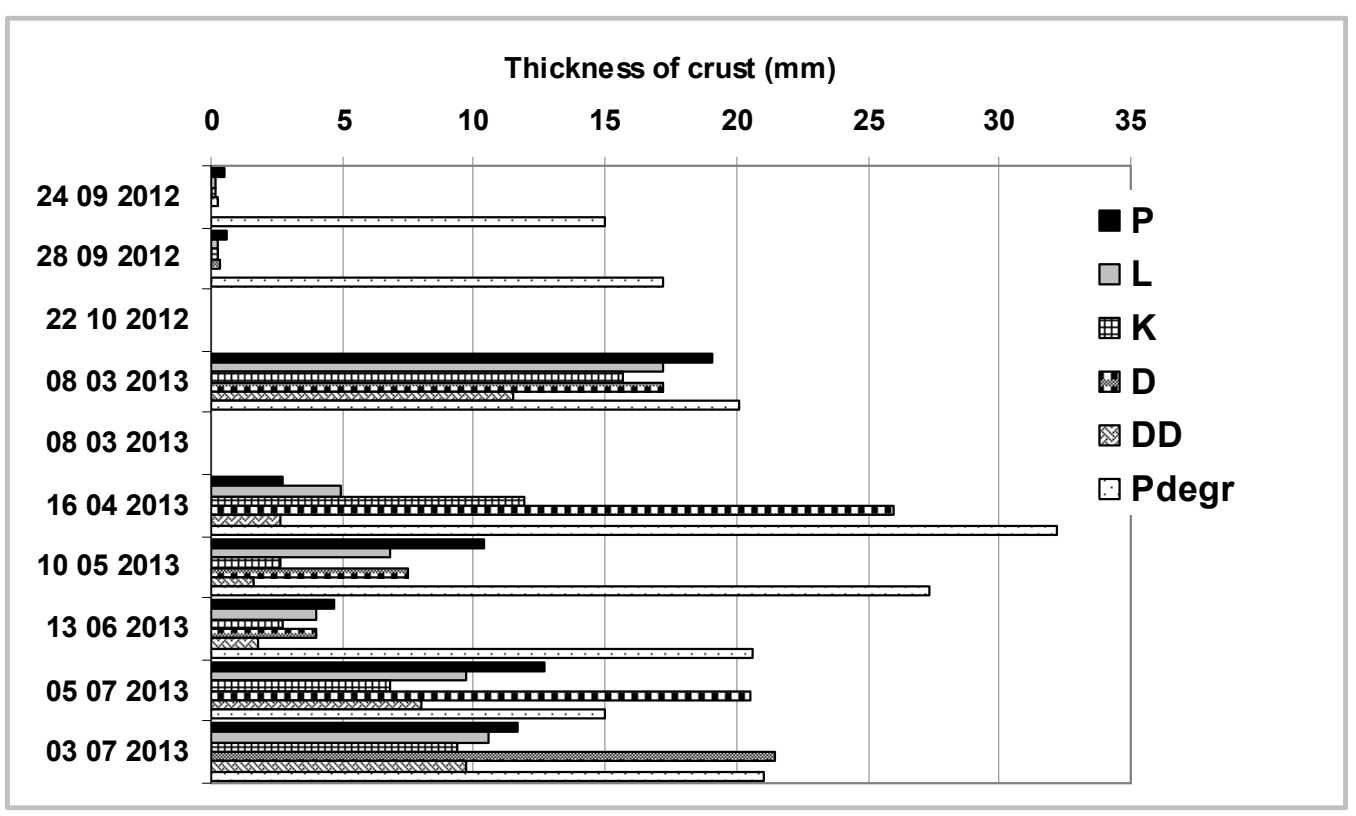

Figure 5. Extension of the surface crust in preserved and in degraded soils (Hatvan, 2013)

\section{Water-logging}

In the first half of year, 2013 a natural induced water logging has been occurred in lowlands and along the underground water veins. It can be stressed that this phenomenon is out of the farming negligence. However, the tillage induced waterlogging has also been occurred both in the surface of the over settled soils and above the compacted pan layers. Trautner and Arvidsson (2003) and Gao et al (2012) described that this phenomenon is typical after-effect of the defective intervention in the soil condition and of tillage performing under constraint.

\section{Conclusions}

Soil structure is an important factor of agricultural soil quality, and its preservation and improvement are keys to preserving soil functions. As Dexter (1988) stressed, tillage alone cannot remedy a soil which has suffered severe structural degradation. 
Tillage can be the first step in soil quality improvement. Next are based on findings derived from long term trials and from monitoring on soils that are suffered from climate induced damages in the first half of year, 2013.

The most important task to avoid frost-dust formation is the reduction of the tilled surface before wintering. The long-term crumb conservation combined with the soil organic material preservation and applying the carbon conserving tillage may prevent the dust formation that prior stage to the siltation in critical periods. Covering the surface in the required rate - min. $45 \%$ but it may vary between $45-65 \%$ - helps to maintain crumb formation and to prevent surface runoff. In a soil containing low ratio of dust, silting process may also lesser and crust formation appears at most sporadically.

Preventing the dust formation and the dust leaching which extends the former compaction layer are the most important steps in the alleviation steps. The depth of the inter-row cultivation is quite shallow and by this means it disturbs slightly the compacted seedbed base. That's all the more reason for the next sowing periods avoiding the over-consolidation of the seedbed-base in wet soil.

The natural induced water-logging is to be managed by regional water regulation. The solution of the farming induced water stagnation requires local and field level management.

The further tasks are to estimate the degree of the probable damage and then taking the initial steps in prevention and later in soil remediation.

Acknowledgements. Research was supported by the TÁMOP-4.2.A-11/1/KONV, Research Centre of Excellence- 17586-4/2013/TUDPOL and by the agricultural business: GAK Training Farm, at Józsefmajor, and P.P. Orahovica d.d.

\section{REFERENCES}

[1] Baumhardt, R.L., Unger, P.W., Dao, T.H. (2004): Seedbed surface geometry effects on soil crusting and seedling emergence. - Agron. J. 96: 1112-1117.

[2] Birkás, M. (2011): Tillage, impacts on soil and environment. In: Glinski, J; Horabik, J; Lipiec, J. (ed.) Encyclopedia of Agrophysics. Springer Dordrecht, 903-906.

[3] Birkás, M. (2012): Challenges faced by the practice of soil tillage in Hungary and in the Pannonian region. In: Birkás M. (ed.) Soil-School. What to learn from and what to teach about soils. Szent István Egyetemi Kiadó, Gödöllö, 432-451.

[4] Birkás, M., Kalmár, T., Kisic, I., Jug, D., Smutny, V., Szemők, A. (2012): A 2010. évi csapadék jelenségek hatása a talajok fizikai állapotára (The effects of rainfall events in 2010 on the physical soil conditions). Növénytermelés 61(1):7-36.

[5] Csorba, Sz., Farkas, Cs., Birkás, M. (2011): Kétpórusú víztartóképesség-függvény a talajmüvelés-hatás kimutatásában (Dual porosity water retention curves for characterizing the effect of soil tillage). - Agrokémia és Talajtan 60 (2): 335-342.

[6] Csorba, Sz., Farkas, Cs., Birkás, M. (2012): An analysis of the water retention capacity function of a soil of a heterogeneous pore structure in soil conserving tillage systems. Növénytermelés 61(Suppl.): 251-254.

[7] Dagesse, D. F. (2013): Freezing cycle effects on water stability of soil aggregates. - Can. J. Soil Sci. 93: 473-483.

[8] Dexter, A. R. (1988): Advances in characterization of soil structure. - Soil Till. Res. 11: 199-238.

[9] Dvoracsek, M., Di Dléria, J., Klimes-Szmik, A. (1957): Talajfizika és talajkolloidika (Soil physics and soil colloics). Akadémiai Kiadó, Budapest, 390-418. 
[10] Fang, H.Y., Cai, Q. G., Chen, H., Li, Q. Y. (2007): Mechanism of formation of physical soil crust in desert soils treated with straw checkerboards. - Soil Till. Res. 93: 222-230.

[11] Gallardo-Carrera, A., Léonard, J., Duval, Y. Dürr, C. (2007): Effects of seedbed structure and water content at sowing on the development of soil surface crusting under rainfall. Soil Till. Res. 95: 207-217.

[12] Gao, W., Watts, C.W., Ren, T., Whalley, W.R. (2012): The effects of compaction and soil drying on penetrometer resistance. - Soil Till. Res. 125: 14-22.

[13] Garamvölgyi, Á., Hufnágel, L. (2013): Impacts of climate change on vegetation distribution No. 1. Climate change induced vegetation shifts in the Palearctic region. Appl. Ecology and Env. Res. 11(1): 79-122.

[14] Guo, Z., Wang, D.Z. (2013): Long-term effects of returning wheat straw to croplandson soil compaction and nutrient availability under conventional tillage. - Plant, Soil and Environ., 59: 280-286.

[15] Jolánkai, M., Nyárai, H. F., Kassai, M. K.. et al. (2013): A water stress assessment survey based on the evaportranspiration balance of major field crop species. - Növénytermelés 62(Suppl.): 351-354.

[16] Kalmár, T., Csorba, S., Szemők, A., Birkás, M. (2011): The adoption of the rain-stress mitigating methods in a damaged arable soil. - Növénytermelés 60(Suppl.): 321-324.

[17] Kalmár, T., Pósa, B., Sallai, A., Csorba S., Birkás M. (2013): Soil quality problems induced by extreme climate conditions. - Növénytermelés 62 (Suppl.): 209-212.

[18] Ladányi. M., Gaál. M., Hufnágel, L. (2003): An agro-ecological simulation model system. . - Appl. Ecology and Env. Res. 1(1): 47-74.

[19] Lamandé, M., Schjønning, P. (2011): Transmission of vertical stress in a real soil profile. Part I: Site description, evaluation of the Söhne model, and the effect of topsoil tillage. Soil Till. Res. 114: 57-70.

[20] Milhoffer, S. (1897): Talajkimerülés (Soil exhaustion). Könyves Kálmán Rt., Budapest

[21] Morris, N.L., Miller, P.C.H., Orson, J.H., Froud-Williams, R.J. (2010): The adoption of non-inversion tillage systems in the United Kingdom and the agronomic impact on soil, crops and the environment-A review. - Soil and Tillage Research 108: 1-15.

[22] Mueller, L., Shepherd, G., Schindler, U., Ball, B.C., Munkholm, L.J., Hennings, V., Smolentseva, E., Rukhovic, O., Lukin, S., Hui, C. (2013): Evaluation of soil structure in the framework of an overall soil quality rating. - Soil Till. Res. 127: 74-84.

[23] Sinha, T., Cherkauer, K. A. (2010): Impacts of future climate change on soil frost in the midwestern United States. - J. of Geophysical Res., 115: D08105, doi:10.1029/2009JD012188, 2010

[24] Sváb, J. (1981): Biometriai módszerek a kutatásban (Biometrical methods in research work). Mezőgazdasági Kiadó, Budapest.

[25] Szalai, S., Lakatos, M. (2013): Precipitation climatology of the Carpathian region and its effects on the agriculture. - Növénytermelés 62(Suppl.): 315-318.

[26] Trautner, A., Arvidsson, J., 2003. Subsoil compaction caused by machinery traffic on a Swedish Eutric Cambisol at different soil water contents. - Soil Till. Res. 73: 107-118.

[27] Várallyay, G. (2011): Water-dependent land use and soil management in the Carpathian basin. - Növénytermelés 60(Suppl.): 297-300.

[28] Várallyay, G. (2013): Soil moisture regime as an important factor of soil fertility. Növénytermelés 62(Suppl.): 307-310. 